\title{
Septic Pulmonary Emboli Related to Infected Arterial Thrombi in an Extensively Burned Patient
}

\author{
Tetsuji Nishikura1, Taiji Ishii' ${ }^{1}$, Shiori Ikemura², Masakazu Ono \\ Shuichi Kozawa ${ }^{1}$
}

\begin{abstract}
A 52-year-old woman who presented with severe burns developed arterial thrombi because of the insertion of a monitoring catheter. We took a conservative management approach, but the patient soon developed bacteremia and her condition worsened.She subsequently died of sepsis including septic pulmonary emboli, the foci of which were strongly suspected to be the arterial thrombi. If a monitoring catheter is mandatory in compromised patients, it should be inserted with extreme caution and care. Moreover early removal of arterial thrombi that develop in such patients is needed, because these thrombi could become infectious foci of persistent bacteremia.
\end{abstract}

(JJAAM $2007 ; 18: 763-8$ )

Key words: compromised host, insertion of arterial monitoring catheter, sepsis, iatrogenic complication Accepted for publication on 2007 May 15, $2007 \quad$ (07-020)

\section{Introduction}

Arterial catheterization of critically ill patients is frequently required for continuous arterial pressure monitoring and blood sampling. The case reported here was that of a severely burned patient who developed infected arterial thrombi in the right groin as a result of insertion of an arterial monitoring catheter into the right femoral artery. The infected thrombi resulted in sepsis, including septic pulmonary emboli.

To our knowledge, no case was reported that deals with septic pulmonary emboli related to infected arterial thrombi.

\section{Case summary}

A 52-year-old woman with a history of depression sustained extensive burn injuries. Before this injury, her past medical history was notable only for depression. She was initially sent to a local hospital. There she was intubated

\footnotetext{
${ }^{1}$ Hyogo Emergency Medical Center

${ }^{2}$ Department of Anesthesia, Kobe Red Cross Hospital

Corresponding to Author:

3-1 Wakinohama Kaigan-Douri 1 chome, Chuo-ku, Kobe-City, Hyogo prefecture 651-0073 JAPAN
}

nasotracheally and the fluid resuscitation was initiated based on Parkland's formula. Because the burn area was extensive, she was transferred to our emergency medical center.

At the center, we first assessed the burn area using the Lund and Browder burn chart. It revealed that the burn area was about $35 \%$ of the patient's total body surface area (TBSA). Second-degree burns comprised 3\% and third-degree was $32 \%$ of TBSA. The neck, upper anterior trunk, and upper extremities had third-degree burns and the face and posterior trunk, second-degree.

We performed escharotomies of the chest and upper extremities and examined the tracheobronchial tree using a bronchofiberscope. Erythema and minimal hemorrhage of the trachea and bronchus were present. Next, we applied dressings, covering the third-degree burn area with silver sulfadiazine and the face with an open dressing of povidone iodine. We transferred the patient to the intensive care unit, where we continued the management of her burn wounds.

We were able to prevent the development of early burn shock by intravenous fluid infusion. Subsequently, we performed surgical procedures three times, on days 6,13 , and 18 .

On day 6, we performed fascial excision in neck, anterior shoulder, and anterior trunk where full-thickness skin burns had occurred. We then applied a split-thickness mesh 
graft (3:1) or split-thickness pinch graft using skin from donor sites on the patient's left thigh and lower leg. On day 13 , we performed a second operation, completing tangential excision of the burn area on the left upper extremity. We grafted split-thickness pinch grafts, which were harvested from the patient's right lower leg. On day 18, normal skin from the right thigh was pinch-grafted onto the right shoulder and the area of the posterior trunk that had sustained third-degree burns.

In these three operations, the grafted area where cast fixation could be done was fixed by cast and the other areas were fixed by tie-over method for about 7 days. Then we released the fixation and evaluated the grafted skin. About $70 \%$ of the total grafted skin area engrafted.

We dressed the grafted areas daily, and most of these areas continued to show no evidence of severe infection. Re-epithelialization began on the newly formed granulation tissue from the grafted skin.

However, in areas such as shoulders, left extremity, and the donor site on the left thigh, infection had developed, with cultures showing growth of Pseudomonas aeruginosa. From day 25, we began hydrotherapy using a heated shower. In response to this intervention, the infected areas showed gradual improvement.

Although the patient's wounds and her physical condition were apparently stable, she abruptly developed arterial thrombi. The patient died because of sepsis, including septic pulmonary emboli. These septic pulmonary emboli were strongly thought to be related to infected arterial thrombi formed by the percutaneous arterial cannulation. In the discussion that follows, we summarize, in a timeline, the sequential interventions and findings that were related to the patient's death. These include infection results (the results of culture of various sites), aspects of venous and arterial catheter insertion, and care, data from blood samples and so on.

Fig. 1 indicates the treatment course. On day 26 after admission, we observed a gradual decrease in the platelet count of peripheral blood. At that time, an arterial catheter used for hemodynamic monitoring and blood sampling (arterial line kit, 20 gauge; Argon, Athens, TX, USA) had been inserted into the right superficial femoral artery, and a central venous catheter (Arrow-Howes Multi-lumen Antecubital Central Venous Catheterization set 7 Fr., 3 lumen, $60 \mathrm{~cm}$ catheter length, 0.035 -inch diameter, springwire guide Arrow International Inc., PA, USA) into the right femoral vein, those catheters had been reinserted on day 20. The blood culture that was performed 2 days earlier (on day 24) was still negative.
On day 28 , the cultured blood still showed no growth of bacteria. On day 30 , the peripheral platelet count was still decreasing, falling to below $50000 / \mathrm{mm}^{3}$. On day 31 , the blood culture indicated the growth of $P$. aeruginosa, and we began culture-specific antibiotic treatment.

On day 33, the platelet number was still decreasing. Conversely, the value of D-dimer in serum increased (Fig. 1). We changed the insertion sites of venous and arterial catheters from the right femoral vein to the left femoral vein and from the right femoral artery to the right radial artery, respectively.

On day 34, the dorsum of the right foot became pale and slightly chill. The dorsalis pedis pulse of the right foot became weaker to touch than the left dorsalis pedis. An enhanced computed tomography (CT) scan of the right leg showed peroneal artery disruption at the middle height of the crus and disruption of the anterior tibial artery above the ankle. The posterior tibial artery barely flowed to the distal side. We began administration of heparin sodium and prostaglandin E1. Although bacteremia was present, the patient was not in a state of septic shock and her condition was barely stable.

The next day (day 35), we performed angiography of the right iliac artery and its distal arteries, which revealed the existence of thrombi in the right external iliac artery and superficial femoral artery. There was blood flow to the distal area (Fig. 2). Because the patient's condition was barely stable, it was decided that thrombectomy by Fogarty catheter was dangerous and too invasive. When there would be shower emboli, total thrombi occlusion in those parts and the thrombi were thought to be the focus of infection, we designed to do thrombectomy. Initially, there were no such situations. We implemented conservative therapy, including anticoagulation and intensive antibiotic treatment.

On day 37 , the patient's respiratory condition suddenly worsened. We performed oral intubation and obtained a chest $\mathrm{CT}$ scan. The radiographic features were bilateral, predominantly peripheral lesions, consisting of multiple nodules and infiltrates. Some nodules had feeding arteries (Fig. 3). We determined from those features that the patient had developed septic pulmonary emboli. Soon after, she progressed to a state of septic shock. We attempted to restabilize her condition by infusion, transfusion, administration of catecholamines and antibiotics, and mechanical ventilation.

Having judged that one or more thrombi were the focus of sepsis, or one of several foci, we performed thrombectomy using a Fogarty catheter. When we exposed the femo- 


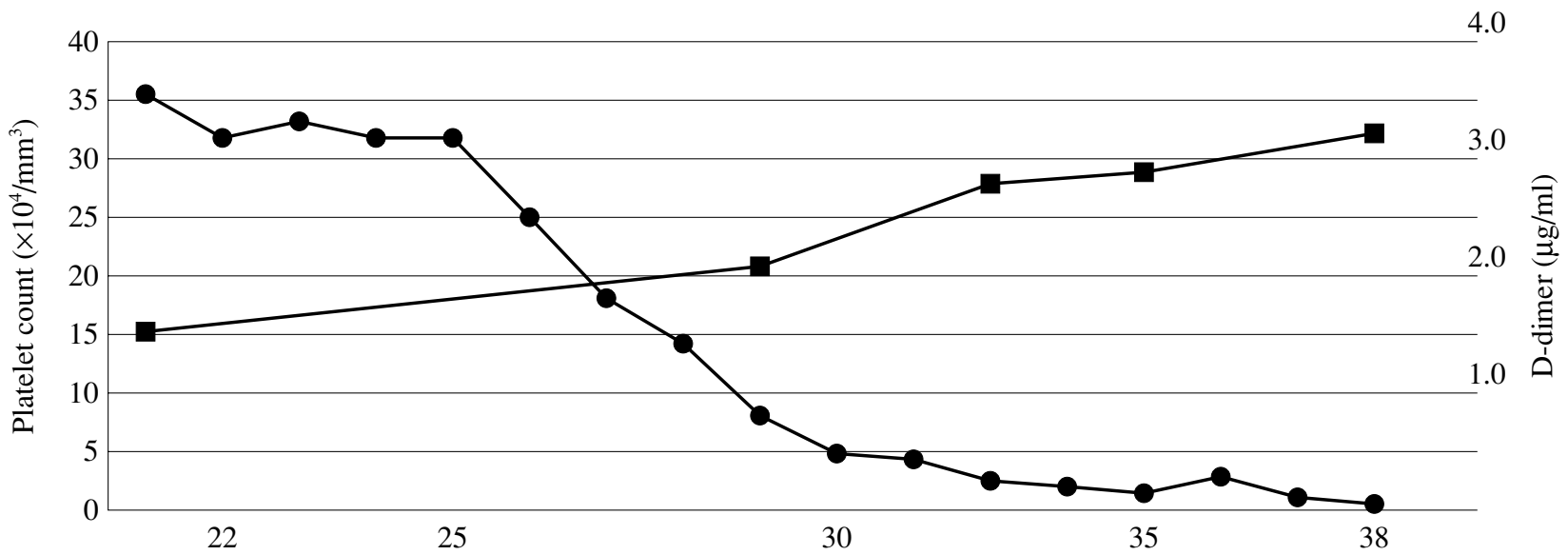

arterial catheter

Day after admission

right femoral artery

central venous catheter

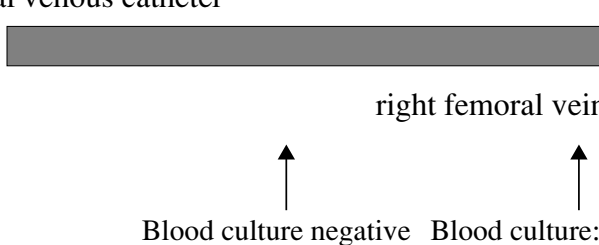

Blood culture negative Blood culture: negative
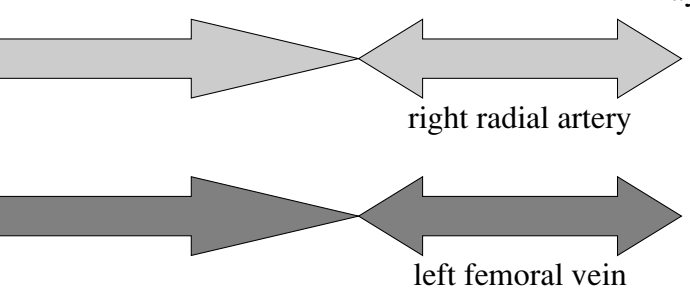


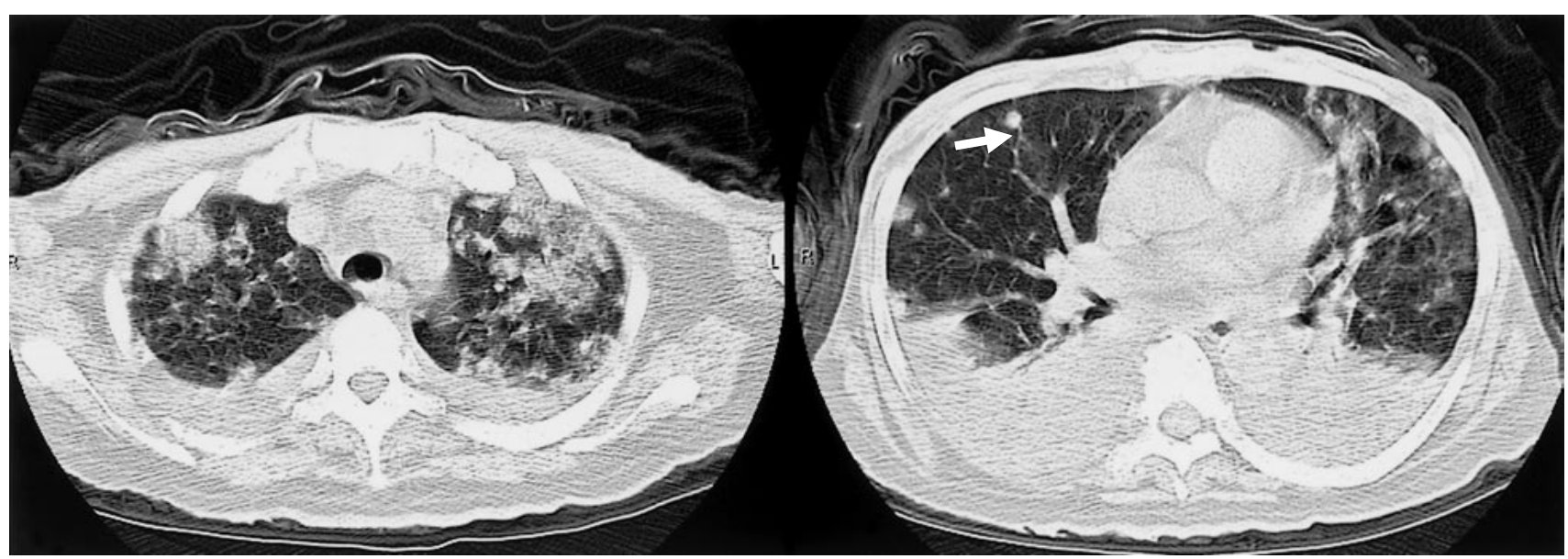

Fig. 3. The radiographic features of the patient's CT scan were bilateral, predominantly peripheral bilateral lesions consisting of multiple infiltrates and nodules (although there were also pleural effusion and atelectasis on the back). Some nodules had feeding arteries [white arrow]. These features are characteristic of septic pulmonary emboli.

ral artery and cut into its anterior wall, we discovered a perforation wound that we suspected had occurred during the cannulation procedure on day 20 .

Although the thrombectomy procedure was successful, the patient's general condition continued to deteriorate and she died on day 38 after the injury. Subsequent culture of the thrombi revealed infection by $P$. aeruginosa.

It should be noted that the arterial and venous catheters were inserted percutaneously, and efforts were made to ensure that the procedure was entirely aseptic. However, when the catheters were reinserted, sometimes multiple punctures occurred.

\section{Discussion}

We neither performed an autopsy of the patient nor obtained a pathological diagnosis. Our diagnosis of septic pulmonary emboli was based solely on the CT finding and laboratory data and therefore may be imperfect.

However, the radiographic features of the chest CT scan that was obtained after the patient's respiratory condition worsened on day 37 after admission showed multiple bilateral peripheral nodules, some of which had feeding arteries (Fig. 3). These are characteristic features of septic pulmonary emboli ${ }^{1-3)}$. Thus, it is likely that the patient had developed septic pulmonary emboli.

The usual causes of septic pulmonary emboli are rightsided bacterial endocarditis, septic thrombophlebitis, infected venous catheters, and occasionally osteomyelitis or infected soft tissue. Presently, an increasing number of patients with long-term indwelling catheters or prosthetic vascular devices are at risk for developing this complica$\operatorname{tion}^{1-3)}$.

In the clinical course of our patient, her blood culture showed the growth of P. aeruginosa on day 31 . She subsequently developed sepsis and septic pulmonary emboli via bacteremia. Until day 31, cultures showed that the growth of bacteria was confined to some grafted burn wounds (shoulders and left extremity), the donor graft site on the left thigh, and the right femoral arterial thrombi. Samples from all these locations showed the growth of $P$. aeruginosa.

When we inserted the arterial monitoring catheter into the right femoral artery, multiple punctures might have produced arterial wall trauma, leading to the formation of arterial thrombi. The thrombi could therefore have been infected directly at the start of thrombi formation by the puncture. Bacteremia followed, which was the cause of sepsis and septic pulmonary emboli. Although the possibility that thrombi were infected during formation by bacteremia from the infected wound could not be denied, its possibility was low, because on days 24 and 28 when arterial thrombi would have been forming, the blood culture showed no growth of bacteria. DNA sequences of $P$. aeruginosa present in the arterial thrombi, blood, and wound, could have clarified the relation, but we did not obtain those DNA sequences.

In either case, infected arterial thrombi formed, causing the patient's physical condition to worsen, leading eventually to sepsis and septic pulmonary emboli.

The complications of insertion of femoral artery catheters for hemodynamic monitoring include bleeding, he- 
matoma, pseudoaneurysm, local infection, catheter-associated infection (sepsis), and thrombus. In these complications, the frequency of developing thrombus and sepsis is $0.18 \%-0.53 \%{ }^{4-6)}$ and $0.44 \%-2 \%{ }^{4,7,8)}$, respectively. The frequency of developing infected thrombi may be very low, and a review of the English literature showed no reports of an infected arterial thrombus secondary to the insertion of an arterial monitoring catheter.

In extensively burned patients, the presence of burn wounds and an immunosuppressed state may increase incidence of infected femoral thrombi. More attention must therefore be paid to catheterization procedures in these compromised hosts. The use of a gentle aseptic technique that does not involve many punctures is needed. Complications can be minimized only by careful technique and selection of the appropriate artery for punctures. Multiple punctures predispose to damage of arterial wall. Also of importance, the indwelling time of the catheter must also be kept as short as possible. Retrospective review of this case leads us to believe that if we had performed the thrombectomy earlier, when the thrombus was first discovered in our patient, her clinical course would probably have been different.

In summary we have described the development of infected femoral artery thrombi secondary to insertion of an arterial monitoring catheter in an extensively burned patient. The infected arterial thrombi were strongly related to the subsequent development of septic pulmonary emboli. In compromised patients, such as the patient we described, gentle and aseptic insertion of catheters is essen- tial. Moreover an early removal of arterial thrombi developed in these compromised patients would be needed because thrombus would become infectious focus of persistent bacteremia.

\section{References}

1) Kuhlman JE, Fishman EK, Teigen C: Pulmonary septic emboli: diagnosis with CT. Radiology 1990; 174: 211-3.

2) Iwasaki $Y$, Nagata $K$, Nakanishi M, et al: Spiral CT findings in septic pulmonary emboli. Eur J Radiol 2001; 37: 190-4.

3) Wong KS, Lin TY, Huang YC, et al: Clinical and radiographic spectrum of septic pulmonary embolism. Arch Dis Child 2002; 87: 312-5.

4) Scheer B, Perel A, Pfeiffer UJ: Clinical review: complications and risk factors of peripheral arterial catheters used for haemodynamic monitoring in anaesthesia and intensive care medicine. Crit Care 2002; 6: 198-204.

5) Durie M, Beckmann U, Gillies DM: Incidents relating to arterial cannulation as identified in 7525 reports submitted to the Australian incident monitoring study (AIMS-ICU). Anaesth Intensive Care 2002; 30: 60-5.

6) Riker A, Gamelli R: Vascular complications after femoral artery catheterization in burn patients. J trauma 1996; 41: 904-5.

7) Thomas F, Burke JP, Parker J, et al: The risk of infection related to radial vs femoral sites for arterial catheterization. Crit Care Med 1983; 11:807-12.

8) Gurman GM, Kriemerman S: Cannulation of big arteries in critically ill patients. Crit Care Med 1985; 13: 217-20. 
症例報告

\section{感染性動脈血栓形成が原因と考えられる敗血症性肺塞栓症を発症した 重症熱傷患者の一例}

$\begin{array}{ll}\text { 西倉 哲司 }{ }^{1} & \text { 石井 } \quad \text { 大嗣 }^{1} \quad \text { 池村志緒里 }^{2} \quad \text { 小野 } \text { 真義 }^{1} \\ \text { 小澤 } & \text { 修一 }\end{array}$

要旨 緒言:重症熱傷患者治療中に観血的動脈圧モニターカテーテル挿入に起因した感染性の動脈血栓形成から 敗血症性肺塞栓症の発症というきわめてまれな症例を経験したので報告する。症例:52歳の女性。自宅の火災に

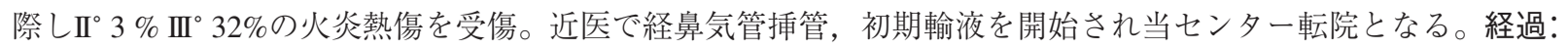
初期ショック期離脱後三度, 焼痂切除及び植皮術を行った。術後経過良好であったが, 数回穿刺を試みた動脈圧 モニターカテーテル挿入に起因すると考えられる血栓を右大腿動脈内に認めるようになった。患者の状態が落ち 着いていたので, 動脈完全閉塞·shower emboliの発症・感染性血栓と判断した場合に血栓除去を予定し, 当初は 保存的に加療した。その後血液培養が陽性となり (後に判明する除去血栓と同じ細菌), しばらくして呼吸状態も 悪化した。挿管の上呼吸管理。胸部 CTでは肺野末梢に栄養血管を伴った多発性の結節陰影があり, 敗血症性肺 塞栓症を示唆する所見であった。感染性血栓と判断しFogatyカテーテルによる血栓除去を行った。しかし患者は その後敗血症で死亡した。考察: 本症例は, 感染性動脈血栓が関与する敗血症性肺塞栓症例であったが, 検索し 得た範囲では症例報告はなく, まれな経過をたどった 1 例と思われた。ただ後に判明した感染性血栓の除去を, 患者が落ち着いている早期に実施していれば違った経過をたどったかも知れない。結語:まれな経過をたどった 重症熱傷患者の症例を報告した。重症熱傷患者など, compromised hostへの必要不可欠のカテーテルの挿入は, 普 段以上に愛護的かつ無菌的操作が必要であると思われた。まれではあるが，易感染患者に挿入操作による動脈血 栓が見つかったときは感染性の可能性もあり早期の除去が必要かも知れない。

(日救急医会誌 $2007 ; 18: 763-8$ )

キーワード : 易感染性宿主, 観血的動脈圧モニターカテーテル挿入, 敗血症, 医原性合併症

${ }^{1}$ 兵庫県災害医療センター 2 神戸赤十字病院麻酔科

著者連絡先：干 651-0073 兵庫県神戸市中央区脇浜海岸通 1-3-1／原稿受理日：2007 年 5 月 15 日（07-020） 